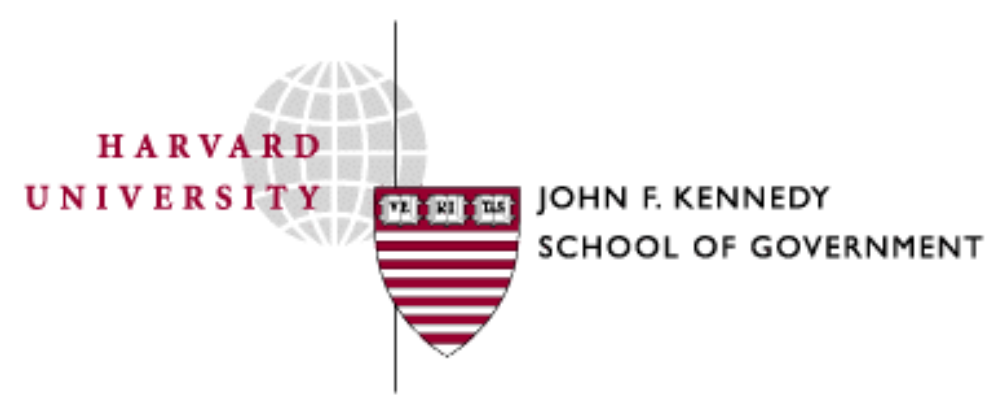

Faculty Research Working Papers Series

\title{
Regulation by Generalization
}

\section{Frederick Schauer and Richard Zeckhauser}

\section{August 2005}

\section{RWP05-048}

This paper can be downloaded without charge from:

http://ksgnotes1.harvard.edu/Research/wpaper.nsf/rwp/RWP05-048

or

The Social Science Research Network:

http://ssrn.com/abstract=896125

The views expressed in the KSG Faculty Research Working Paper Series are those of the author(s) and do not necessarily reflect those of the John F. Kennedy School of Government or Harvard University. Copyright belongs to the author(s). Papers may be downloaded for personal use only. 
Draft - 07/29/2005

\title{
REGULATION BY GENERALIZATION
}

\author{
Frederick Schauer and Richard Zeckhauser ${ }^{1}$
}

\begin{abstract}
"Where there's smoke, there's fire," says a venerable adage that informs many of our everyday decisions. Although what looks smoke may have a cause other than fire, smoke is so often the indicator of fire that it is rarely a bad strategy to presume the presence of fire from the observation of smoke. Similarly, when a promised payment does not arrive we assume it was not sent, even though checks sometimes do get lost in the mail. When a road is slippery in winter we presume the cause is ice, even though it could be spilled oil. And when a physician sees yellowing skin and nausea she concludes that her patient has hepatitis, although some rare diseases produce identical symptoms.
\end{abstract}

Yet although it is common to infer a cause from the presence of its typical indicator, much of legal and regulatory practice is to the contrary. In criminal, civil, and regulatory law, we are often more reluctant to take action based on the likely cause of an observed consequence than a physician is to prescribe treatment based on the likely cause of observed symptoms. On the whole, our regulatory apparatus appears to believe that it needs more direct evidence than is provided by the inference from observed smoke to unseen fire, and that individuals subject to regulation, liability, or punishment must be given an opportunity to demonstrate that even the most reliable of indicators has produced the wrong conclusion in their particular case. The inferential logic lying behind "Where there's smoke, there's fire" may be satisfactory for presuming the existence of fire, it seems, but not for presuming the existence liability-incurring acts.

1

Schauer is Frank Stanton Professor of the First Amendment and Zeckhauser is Frank Plumpton Ramsey of Political Economy, John F. Kennedy School of Government, Harvard University. Earlier versions of this Article have been presented at the Arizona State University, New York University, and Stanford Law Schools. Comments by and assistance from Miriam Avins, Clayton Gillette, Stephen Schulhofer, William Simon, and Sam Walsh have helped enormously. Research support from the Joan Shorenstein Center on the Press, Politics and Public Policy is gratefully acknowledged.

In this Article we argue that the common aversion to what we can call evidentiary regulation or regulation by generalization makes little sense. Although it is often thought repugnant to hold people legally responsible on the basis of probabilistically reliable but non-universal indicators of wrongful or regulable conduct, we argue that this reaction is a product of undue skepticism about probabilistic inference coupled with undue faith in the reliability and costlessness of eyewitness and other forms of sensory observation. Moreover, even the most seemingly direct forms of regulation - the typical speed limit, for example - rely on inferences closely related to the inference from smoke to fire. Accordingly, using "Where there's smoke, there's fire" as a heuristic for regulation may turn out to have more merit than is commonly believed. 


\section{Bentham on Presumed Offenses}

We can focus our analysis by going back to Jeremy Bentham. In a largely ignored paragraph in Principles of the Penal Code, Bentham describes what he calls presumed offenses. ${ }^{2}$ Presumed offenses were unusual, Bentham thought, because they punished people not for engaging in wrongful or "injurious" conduct, but for conduct that, even though not wrong in itself, justified an inference that those engaged in it were doing something else that was genuinely wrong. With respect to presumed offenses, the likelihood that someone had committed a genuine wrong warranted punishing them for acts that were indicative of, but not coincident with, wrongful conduct. Because these indicative acts were evidence of the wrongful acts, Bentham also referred to presumed offenses as evidentiary offenses.

2 Jeremy Bentham, Principles of the Penal Code, Book IV, chap. XV, in The Theory of Legislation 425-27 (Richard Hildreth from Etienne Dumont trans., C.K. Ogden, ed., 1931)

As an example, Bentham noted the crime ${ }^{3}$ of possessing shipwrecked property (presumably including the ship itself) with altered or obliterated markings. In seventeenth-century England, Bentham tells us, it was an offense to be found in possession of shipwrecked property whose identifying marks had been painted over or otherwise obliterated. The law was based not on the belief that it was intrinsically wrong to own shipwrecked property with altered markings; after all, a lawful acquirer of such property might wish simply to remove the traces of a previous owner. ${ }^{4}$ But although such innocent explanations were possible, the offense as based on the fact that in almost all cases the identifying marks would have been removed for less benign reasons, typically to disguise a ship or property that had been stolen from its rightful owner. So although there might be shipwrecked property with innocently obliterated markings, such a high percentage of altered markings were illicit, said Bentham, that all property with altered markings could be presumed to have been stolen. Making possession of such property an offense thus efficiently punished those who had obtained property illegally. 3

Our analysis is not limited to regulation by the criminal law, but we start with crimes partly because Bentham did, and partly because crimes are the extreme case. If it is more acceptable than commonly believed to regulate indirectly through the criminal law, then it is, a fortiori, more acceptable than common believed to regulate indirectly through the civil law or through other forms of regulation.

${ }^{4}$ A desire well understood by those of us who have dedicated books to people with whom we are no longer so closely associated.

${ }^{5}$ Although Bentham did not discuss this explicitly, part of the efficiency of such a course of action would come from the fact that if the existence of such a law were widely known and if the law were effectively enforced, the market for such stolen property would likely dry up almost completely. 
As a further example, Bentham described a law in which a woman who failed to report the birth of a subsequently missing child was deemed guilty of infanticide. As with the possession of shipwrecked property with altered markings, the act itself is relatively innocent. Moreover, there are innocent explanation; for example, an embarrassed unwed mother might send the child off to live with distant relatives. Yet innocent explanations were unlikely, and failing to report a proved birth of a missing child was deemed infanticide not because it was infanticide, but because it probabilistically even if not necessarily indicated that an infanticide had taken place.

\section{Evidentiary Offenses Today}

Neither the offense of possession of shipwrecked property with altered markings nor treating unreported births as infanticide survives into the twenty-first century. ${ }^{6}$ Yet evidentiary offenses are still with us. For example, anyone who enters or leaves the United States with more than $\$ 10,000$ in currency or other monetary instruments must report to customs authorities the amount transported, its origin and destination and route, the identity of its owner, and the relationship between the transporter and the owner. ${ }^{7} \mathrm{~A}$ person failing to disclose this information is guilty of a felony and liable to a $\$ 250,000$ fine and up to five years' imprisonment. Yet this reporting requirement is not, as are similar requirements in countries with strong monetary controls, connected with the enforcement of currency or monetary restrictions; in the United States it is lawful to bring in or take out as much currency as one pleases as long as the transaction is reported to the authorities.

6

Possessing a weapon with an obliterated serial number is, however, a federal crime in the United States. 18 U.S.C. §922(k)(2002). Another of Bentham’s examples, treating the possession of stolen property as an offense, is quite common. And although the offense is based in part on a desire to punish "fences" and other knowing receivers of stolen property, it also remains based in part on the presumption that the possessor is often the thief. See Jacqueline E. Ross, Valuing Inside Knowledge: Police Infiltration as a Problem for the Law of Evidence, 79 Chi. - Kent L. Rev. 1111, 1121-22 (2004).

31 U.S.C. $§ 5316$ (2002). Implementing details can be found in 31 C.F.R. §103.23(a) (2004).

The reporting requirement, however, is not merely bureaucratic overkill. Rather, it is based on the fact that people who travel into and out of the United States with large amounts of cash are substantially more likely than the baseline traveler to be engaged in illegal transactions, typically money laundering or narcotics trafficking. Thus, because innocent people rarely carry this much cash when traveling internationally, and because people who do are usually (or at least more likely) up to no good, the law presumes that anyone entering or exiting the country with so much unreported cash is hiding an illegal transaction. The offense of failing to report is thus primarily an evidentiary offense, closely akin to possessing shipwrecked property or failing to report the birth of a subsequently missing child. As in Bentham's examples, failing to report the transportation of a large amount of currency is an offense not because it is itself harmful, 
but because it probabilistically even if not universally indicates that a wrongful act has occurred, and because guilty explanations are so much more probable than innocent ones. Nearly all who are guilty of the evidentiary offense, therefore, will have done something (else) illegal, even it that something else cannot be proved directly, and in some cases never verified at all. And if people who fail to report are sometimes guilty of nothing else - perhaps they distrust credit cards and innocently forgot to report the cash they were transporting - the fact that anyone entering or leaving the United States is put on notice of the criminality of non-reporting is thought sufficient to prevent what otherwise might be a major injustice.

${ }^{8}$ And who in any event would be far more able easily to prove their innocence if challenged.

It is true that reporting the transaction appears to prevent a "major" injustice, but the requirement of reporting even innocent transactions is more than a momentary inconvenience. The very fact of reporting raises the government's (and especially the tax authorities') scrutiny of all of the reporter's actions above what it would otherwise have been and above what it is for most ordinary citizens. Yet although the reporting requirement may thus impose a cost on anyone required to report, it imposes a higher cost on the narcotics dealers and the money launderers than on ordinary citizens, largely because of the signaling effect, the way in which some actions because of their signals are more costly for some individuals than for others. See A. Michael Spence, Market Signaling: Information Transfer in Hiring and related Screening (1974); Peter C. Cramton, Strategic Delay in Bargaining with Two-Sided Uncertainty, 59 Rev. Econ. Study 205 (1992); A. Michael Spence, Job Market Signaling, 87 Quart. J. Econ. 355 (1973). Thus even if the law were widely known, it may be that narcotics dealers would find it difficult to avoid carrying large amounts of cash when ordinary citizens would not, and thus the law would be an effective trap for the dealers who would be compelled to signal their criminal activity.

A similar offense is that of possessing more than a specified quantity of illegal narcotics. Although possessing any quantity of various designated narcotics is typically a crime, possessing more than a statutorily specified amount is commonly treated far differently. In such cases, the law presumes that people who possess more than the specified quantity are drug dealers. ${ }^{10}$ Although this example is less clean than the previous examples possessing large quantities of narcotics for personal use is not as innocent as innocently carrying large amount of cash or naively and innocently possessing shipwrecked property from which identifying marks have been removed, for example - once again the offense is based on the principle that it can be a crime to do something not itself wrong (or as wrong), but which indicates that the person doing it is almost but not quite certainly doing something inherently wrong. 10

A typical example is the Florida law providing that anyone possessing more than 28 grams of cocaine is guilty of trafficking in cocaine. Florida Statutes §893.135(1)(b)(1) (Supp. 2002).

${ }^{11}$ In establishing offenses based on indicators of wrongful behavior, the authorities presumably employ at least an implicit model that looks at a range of relevant probabilities for three different groups: the guilty, the knowing-innocent, and the 
ignorant-innocent. The question is then one of determining the likelihood that a random individual falls into each group. Similarly, it must be determined how likely it is that a member of each group will engage in the indicator behavior, and how likely is it that they will be able to exonerate themselves upon close examination. The payoffs to the authorities - e.g., what is the implicit cost if an ignorant-innocent is punished? - are then the second component of the model. Thus the establishment of the offense will ideally be the product of a determination that false positives (finding an innocent person guilty) are unlikely as well as inexpensive relative to the likelihood and costs of failing to convict those who are guilty. More sophisticated models would look at how likely it is that the bad behavior itself, and not merely its indicator, is deterred. If prohibiting people from carrying more than $\$ 10,000$ in undeclared cash into the country does not discourage traveling drug dealers or drug couriers, but merely forces them to hide their cash more effectively, the regulation will have only modest beneficial effect, that coming from the way in which the regulation raises slightly the cost of dealing in drugs.

Other presumed offenses have a similar justification. The possession of drug paraphernalia is made a crime not primarily because of the intrinsic harmfulness of the pipes, spoons, mirrors, scales, and other devices employed in narcotics use. Indeed, each of these items, taken alone, is capable of quite legal and valuable use. Rather, the possession of such paraphernalia, especially in conjunction, ${ }^{12}$ is taken to be such a strong indicator of drug use that its possession, even when no drugs are found, is made a crime as a way of punishing users of illegal drugs. ${ }^{13}$ A similar approach partly explains the crime of possession of burglar tools, and so too with he fact that even where possession of a shotgun is legal it is typically unlawful to possess a shotgun with a shortened ("sawed-off") barrel, the explanation being that possession of such a weapon is almost always but not necessarily in aid of planned illegal activity. Some of these additional examples present a further complication. In examples such as the possession of burglar tools or drug paraphernalia, the possession that is made an offense might be considered not as evidence of a crime that has already occurred, but as evidence of preparation for a primary offense that has yet to take place. Or the goal of the law criminalizing possession might simply be to decrease the quantity of devices that could be but are not yet being used to facilitate a particular criminal act. Yet even if we exclude such preparatory (as Bentham designated the former class) and facilitative offenses, there remain justifications for these types of laws that are based on punishing conduct that indicates that wrongful acts have likely already taken place. And the presumption that anyone possessing more than a designated quantity of narcotics is trafficking in illegal drugs is based on the same idea. Thus in the case of the true evidentiary offense, unlike the preparatory offense and unlike the facilitative offense and unlike inchoate offenses such as attempts and conspiracy, the conduct made unlawful is not conduct that facilitates or prepares for or increases the likelihood of subsequent criminal acts, but rather is conduct that provides evidence that criminal acts have already been committed.

12 13

See, for example, Michie's West Virginia Code ch. 60A-4-403a (2000), which makes criminal all knowing possession of paraphernalia "primarily useful as drug devices" 
(emphasis added), with the logical implication being that even possession of devices for purposes encompassed by the logical space between "primarily" and "exclusively" is nonetheless a criminal offense. See also the discussion of the Arizona possession statute in Abbe M. Goncharsky, Case Note, Drug Paraphernalia Charges and Proposition 200: State v. Estrada, 44 Ariz. L. Rev. 283 (2002).

14

Most devices employed in burglaries, including crowbars, glass cutters, and even lock picks, have significant lawful uses, and thus the typical burglar tools conviction involves possession of a multiplicity of individually less suspicious implements whose presence in combination is highly unlikely to be for any lawful use. Good examples include the simultaneous possession of a crowbar and a bent coat hanger (Burgess v. Bintz, 2002 U.S. Dist. LEXIS 7168, S.D.N.Y., April 24, 2002), a crowbar, a hacksaw, and a lock pick (People v. Trimmer, 2002 Cal. App. Unpub. LEXIS 6520), and six porcelain fragments from automobile spark plugs (People v. O.M., 2002 Cal. App. Unpub. LEXIS 6565) (jagged porcelain fragments are apparently useful for noiselessly breaking windows). See 18 U.S.C. §922(4) (2002).

Evidentiary offenses remain with us, but they are viewed with suspicion. Bentham himself viewed such offenses as, at best, necessary evils given the realities of imperfect law enforcement, and the modern view is more skeptical yet. Nowadays it is often thought profoundly unjust to find someone guilty of a crime simply because they have done something that indicates wrongful conduct, as opposed to finding them guilty under the suitable standard of proof of having actually done something wrong. In some respects, the evidentiary offense appears to be a form of guilt by association. So in United States v. Bajakajian, for example, a case involving the question whether a $\$ 357,144$ forfeiture for failing to report the transportation of more than $\$ 10,000$ in currency was an "excessive fine" in violation of the Eighth Amendment, a majority of the Supreme Court refused to draw any inferences of culpability for anything more than failing to report from the fact that Mr. Bajakajian has indisputably deliberately chosen not to report his possession of the aforesaid $\$ 357,144$.

16

See Larry Alexander and Kimberly D. Kessler, Mens Rea and Inchoate Crimes, $87 \mathrm{~J}$. Crim. L. \& Criminology 1138 (1997); Douglas Husak, Guns and Drugs: Case Studies on the Principles Limits of the Criminal Sanction, 23 L. \& Phil. 384 (2004).

17

524 U.S. 321 (1998).

The Supreme Court's attitude in Bajakajian of backing away from an obvious but still probabilistic inference is seen in numerous other instances. Consider, for example, the short-lived crime of selling a book or a magazine without a cover. Typically, the copyright page of a mass-market paperback states, "If you purchased this book without a cover you should be aware that this book is stolen property. It was reported as 'unsold and destroyed' to the publisher and neither the author nor the publisher has received any payment for this 'stripped book."' The industry practice underlying this message is that publishers and distributors routinely give retailers full return credit for any unsold book or magazine. But because it would be costly for a retailer to ship back to the distributor every unsold (and now virtually worthless) copy of last week's Time magazine, the retailer is required to return only the cover. When the retailer sends back the covers of 
the unsold copies, he warrants that the contents have been destroyed. The publisher or distributor then gives the retailer credit for each cover that he returns, and all parties save the cost of packing and shipping a large volume of largely worthless paper. If the retailer is of a mind to steal, however, and especially with respect to publications that retain some of their value, he returns the cover but sells the now-coverless book or magazine (albeit at a discount), receiving full credit from the distributor and a discounted payment from the purchaser of the coverless magazine. The notice on the inside cover of paperback books (where the practice is especially prevalent because of the continuing value of the contents) is meant to warn the purchaser of as coverless book as to the nature of the fraudulent transaction to which he is a party.

Because selling books and magazines reported as unsold amounts to stealing from the publisher or distributor, and because identifying culprits is difficult, New York once attempted to prohibit the sale of coverless periodicals. Under the New York law, anyone selling a magazine without a cover was guilty of a crime, with no further requirement to prove that this was part of a fraudulent transaction. New York thus treated the sale of coverless periodicals as an evidentiary offense, presuming any seller of a coverless magazine to be engaged in fraud, even though it is remotely possible to imagine an innocent sale of such a publication. A person selling a coverless periodical was guilty of a crime, and the prosecutor was not required to prove that the sale was itself part of a fraudulent scheme of any kind.

The New York Court of Appeals would have none of this. ${ }^{18}$ In 1961 that court declared the coverless magazine law unconstitutional, concluding that the statute presumed "corruption or impropriety" on the part of anyone selling a coverless magazine, rather than requiring proof of such corruption or impropriety in each individual case. To the Court of Appeals, it was impermissible for a legislature to presume that all sellers of coverless magazines were crooks, when it was actually the case that only most of them were.

In reaching this conclusion, the Court of Appeals demanded an individualized determination of culpability. Only if innocent sellers of coverless books were exempt from prosecution could the law permit the inference that the seller of a coverless book was engaged in a fraudulent transaction. Implicit in the court's conclusion is the premise that justice requires - to put it starkly - that only the wicked be punished. Yet although it seems hard to disagree with this, the conclusion may be too quick and too strong, as a larger look at presumptions can show us. And thus once we understand the error of the New York Court of Appeals, we can then see that the very idea of an evidentiary offense is less offensive than appears at first glance. 18

People v. Bunis, 9 N.Y.2d 1, 210 N.Y.S.2d 505, 172 N.E.2d 273 (1961). The facts of the case, the practice specialization of Mr. Bunis's attorney, and other litigation in which Mr. Bunis was involved (see Bunis v. Conway, 17 App. Div. 2d 207, 234 N.Y.S. 2d 435 (App. Div. 1962)) all provide some reason to believe that Bunis was engaged in the sale of pornographic magazines, a type of publication that typically retains more value for its intended audience well after its publication date than, say, Newsweek, Sports Illustrated, or the Times Literary Supplement. 
III The Fall and Rise of Irrebuttable Presumptions

The instincts that led the New York Court of Appeals to invalidate the presumption that sales of coverless magazines were fraudulent led the Supreme Court of the United States, a bit more than a decade later, to start down a similar path. In 1973 the Court heard a challenge to a University of Connecticut rule presuming that a person with an address outside of Connecticut for any part of the year prior to enrolling for admission was not a resident of Connecticut at the time of admission, and could not be a resident for his or her entire career as an undergraduate.

The significance of this rule came from the fact that, like other state universities, Connecticut charged lower tuition for residents than for non-residents. Indeed, the nonresident tuition was more than three times that for Connecticut residents. Especially when the differential is this great, state universities are constantly on the lookout for students who attempt to claim that they are residents when they are not, or who attempt to change their residency to lower their tuition. Granting lower tuition rates to such students would frustrate Connecticut's desire to ensure that only bona fide Connecticut residents paid the lower rate. In other words, Connecticut suspected, not unreasonably, that almost all students with addresses outside of Connecticut for part of the year prior to matriculation were not the kind of "real" Connecticut residents that Connecticut desired to assist.

19

${ }^{19}$ Vlandis v. Kline, 412 U.S. 441 (1973). 20

Part of the importance of this example lies in the fact that the Connecticut regulation is closer to traditional economic and social regulation than are the prior examples. As will become apparent, our analysis is thus applicable to a broad range of traditional regulatory arenas, as when a financial institution is required to main a specified ratio of liquid assets to liabilities, without attention to how rapidly those liabilities may be called. Similarly, a prime pollution source may be held responsible solely on the basis of an excessive reading by a downstream or downwind monitoring station, even though other nearby smaller sources might in fact have been the cause. And an employer whose percentage of minority managers was far below the employer's percentage of minority workers may be taken to have discriminated, even absent any other proof of actual discrimination. Indeed, the earliest use of numerical quotas and other forms of effects analysis in the racial context arose when courts strongly suspected but could not prove with certainty that unlawful intentional official action was producing racially disproportionate minority enrolment in previously officially segregated public schools. See Swann v. CharlotteMecklenburg Board of Education, 402 U.S. 1 (1971); Green v. County School Board, 391 U.S. 430 (1968).

Yet although Connecticut's probabilistic inference was undoubtedly correct, some people actually do move to Connecticut with every intention that the move be permanent, and not primarily to save money on college tuition. And it is reasonable to suppose that at least a few of such genuine residence-changers move just before enrolling at the University of Connecticut, or while they are students. Thus, they may move to Connecticut for the same legitimate reasons that might lead anyone else to change 
residency - family connections, employment opportunities, romantic involvement, weather, scenic beauty, cultural attractions, or just a desire for change. Under the Connecticut rule, however, none of these bona fide residence-changers could obtain the benefit of lower in-state tuition. Like the opportunistic ("fraudulent" seems too strong here) residence-changers, the bona fide residence-changers must pay higher tuition (obviously a less severe sanction than a criminal penalty) for their entire undergraduate careers just because they had an address outside of Connecticut at some time during the year prior to their entrance or just because the legitimate reasons for changing their residence arose after they had enrolled.

Because the Connecticut rule allowed no exceptions, the Supreme Court ruled in Vlandis v. Kline in 1973 that Connecticut's “irrebuttable presumption” of non-residency violated the Due Process clause. Because none of the bona fide residence-changers were provided an opportunity to show that their situation was different from that of the vast majority of those at whom the rule was directed, the Connecticut rule, announced Justice Stewart, could not be upheld. As with Aristotle's argument in the Nicomachean Ethics that justice demands - through the vehicle of equity - an escape valve for those incorrectly encompassed within the reach of a general rule, ${ }^{21}$ so too did Justice Stewart conclude that procedural justice demands the same for those incorrectly encompassed within the boundaries of an irrebuttable presumption.

The story of the irrebuttable presumption doctrine is a short one. A mere two years after deciding Vlandis v. Kline, the Supreme Court declared dead the doctrine it had so recently created. $^{22}$ Although in the intervening two years the Court had struck down other laws that did not allow individuals to demonstrate that they were within the area over-encompassed by exceptionless general rules, it finally recognized that the irrebuttable presumption doctrine was untenable. ${ }^{24}$ And thus by 1975 the Supreme Court had realized that virtually all legislation classifies imprecisely, consequently making it implausible to strike down, or even consider challenges to, every legislative category whose reach was broader than he evil it was intended to address.

The Supreme Court's ultimate conclusion is plainly correct. The Connecticut approach to residency -- setting a readily observable standard -- is, after all, in very much the same spirit as the minimum voting age, which sets a precise event - one's eighteenth birthday to encompass all those deemed sufficiently mature, civic-minded, invested in the community, or whatever, to cast a ballot. So too with setting a minimum age for driving, on the assumption that all of those under some age - typically sixteen or seventeen - are not mature enough to drive responsibly even recognizing that the generalization applies only to most and not to all of those below the designated age. Now matter how persuasively some fifteen-year-old might argue that she has none of the negative attributes that the minimum driving age was designed to screen out, no one will listen; nor will we give her an exemption from the minimum driving age if she can prove that she is far more responsible than the typical twenty-year old. ${ }^{25}$ All of these minimum ages are irrebuttable presumptions, and so too is the typical speed limit, which prohibits driving in excess of a specified speed without giving the safe driver the opportunity to 
demonstrate that under ideal conditions the reasons for the rule do not apply to him. The Connecticut law simply established a residency rule, and like all rules it was actually or potentially over-inclusive, applying to some people who would have fallen outside of the justification for creating the rule in the first place.

Aristotle, The Ethics of Aristotle - The Nicomachean Ethics, ๆ 1137a-b (J.A.K. Thomson trans. 1953).

22

Weinberger v. Salfi, 422 U.S. 749 (1975).

See, e..g., Cleveland Board of education v. LaFleur, 414 U.S. 632 (1974); United States Department of Agriculture v. Murry, 413 U.S. 508 (1973).

24

As several commentators had recognized from the outset. See Note, Irrebuttable Presumptions: An Illusory Analysis, 27 Stan. L. Rev. 449 (1975); Note, The Irrebuttable Presumption Doctrine in the Supreme Court, 87 Harv. L. Rev. 1534 (1974).

The genuine residence-changer who lived outside of Connecticut at some point in the year prior to matriculation thus falls into the same category as the mature seventeen-yearold who wishes to vote, the responsible fifteen-year-old who wants a driver's license, and the safe driver wishing to drive at seventy-five miles per hour under ideal road conditions. In all these cases the law gathers in some of the innocent along with many of the guilty. Once the Supreme Court recognized the inevitability and frequency of this phenomenon it recognized that it needed to abandon the idea that all legislative classifications not allowing for exceptions were for that reason unconstitutional. ${ }^{27}$ 25 26

And so too with the minimum age -- twenty-one -- for drinking alcoholic beverages.

See Frederick Schauer, Playing By the Rules: A Philosophical Examination of RuleBased Decision-Making in Law and in Life (1991).

27

Of some interest here is United States v. Fior D’Italia, 536 U.S. 238 (2002), in which the Supreme Court upheld an aggregation estimate approach to imposing social security (FICA) taxes on the tip income of restaurant waiters, with Justice Breyer, speaking for the majority, noting that there is no reason to believe that "individualized employee assessments will inevitably lead to a more 'reasonable' assessment of employer liability an an aggregate estimate.” 536 U.S. at 254.

Despite the brief life of the irrebuttable presumption doctrine, cases like Bunis are hardly just relics from an earlier era. The law even today reveals a persistent particularist urge, and a stubborn eagerness to follow the instincts behind the irrebuttable presumption doctrine. Florida law is illustrative and instructive. At about the same time that the New York Court of Appeals decided Bunis, the Florida Supreme Court decided Delmonico v. State, ${ }^{28}$ holding it to be a violation of the United States and Florida Constitutions to punish people for possessing spearguns. Although most speargun uses were unlawful, ${ }^{29}$ the Florida court concluded, the possibility of a lawful use constitutionally entitled a possessor to an opportunity to show that he was an innocent member of a guilty class.

Delmonico represents the law in Florida even today. Since 1963, Florida courts have, on the authority of Delmonico and similar cases, invalidated laws proscribing possession 
of a "hoax bomb," credit cards, and banning the sale to minors and possession by minors of spray-paint and broad-tipped felt markers (the "weapons" of choice or graffiti artists). And it is not just Florida. A 2000 Illinois decision invalidated a conviction for violating the recordkeeping requirements specially applicable to salvage yard operators because the statute had been directed at those who traded in stolen cars and parts, but did not allow a defendant who failed to keep proper records the opportunity to show that he was not the kind of person to whom the law was directed. ${ }^{33}$ Thus, in Illinois, in Florida, in New York (which has never overruled Bunis), and elsewhere, the hold of particularist instincts remains strong, generating a tilt against laws derived from empirical observations of many individuals engaged in some behavior when it comes to assigning individual responsibility. Rather, the particularist urge demands instead that there be "direct" evidence linking specific individuals with the actual behavior that is the state's ultimate concern.

28

155 So. 2d 368 (Fla. 1963).

29

Partly for reasons of danger to other divers, and partly because it was believed to be an unsportsmanlike (and too easy) method of fishing.

30

In the Interest of T.C., a Child, 573 So. 2d 121 (Fla. Ct. App. 1991).

31 32

D.P. v. Florida, 705 So. 2d 593 (Fla. Ct. App.1997).

Indeed, the pull of particularism has a long and illustrious history. From Aristotle to the present, getting to the particulars of this situation or case or person is put forth as an ideal, with generalization seen as at best the lazy or time-saving alternative. Legal scholars celebrate deciding “one case at a time,"” philosophers extol the virtues of particularism in reaching moral conclusions, feminist theorists defend a qualified particularism as preferable to a traditionally male belief in the inherent superiority of generalization and abstraction, and social psychologists talk about looking at each person as an individual, with "going beyond categorization" being "the right thing to do in almost every case.” It may be a century and a half since William Blake said that "[t]o generalize is to be an idiot. To particularize is the alone distinction of merit," may be three decades since the Supreme Court's brief flirtation with the irrebuttable presumption doctrine, but it is clear that the particularist urges that inspired it continue to thrive today.

33 34

People v. Wright, 740 N.E.2d 755 (Ill. 2000).

The same instincts generate the persistent resistance to statistical evidence in civil and criminal trials. Although now more than a half century old, the preference for "direct" evidence and skepticism about probabilistic evidence reflected in Smith v. Rapid Transit, 58 N.E.2d 754 (Mass. 1945) (the inspiration for the famous “blue bus” hypothetical) remains firm. For the flavor of the debate, compare L. Jonathan Cohen, The Probable and the Provable (1977); Judith Jarvis Thomson, Liability and Individualized Evidence, in Rights, Restitution, and Risk: Essays in Moral Theory 225 (1986); and Laurence H. Tribe, Trial by Mathematics: Precision and Ritual in the Legal Process, 84 Harv. L. Rev. 
1329 (1971), with Kaminsky v. Hertz Corp., 288 N.W.2d 426 (Mich. Ct. App. 1979); James Brook, The Use of Statistical Evidence of Identification in Civil Litigation: WellWorn Hypotheticals, Real Cases, and Controversy, 29 St. Louis U.L.J. 293 (1985); and Daniel Shaviro, Statistical-Probability Evidence and the Appearance of Justice, 103 Harv. L. Rev. 530 (1989). 35

Cass R. Sunstin, One Case at a Time: Judicial Minimalism on the Supreme Court (1999). Related particularist themes emerge in more popularized commentaries on the deficiencies of law, as in Philip K. Howard, The Death of Common Sense (1994). 36

Jonathan Dancy, Moral Reasons (1993); Brad Hooker and Margaret Olivia Little, eds., Moral Particularism (2000).

37

Mary Field Belenky, Blythe Clinchy, Nancy Goldberger, and Jill Tarule, Women’s Ways of Knowing: The Development of Self, Voice, and Mind (2d ed., 1997); Carol Gilligan, In a Different Voice: Psychological Theory and Women's Development (1993); Martha Nussbaum, The Fragility of Goodness: Luck and Ethics in Greek Tragedy and Philosophy (1986); Katherine T. Bartlett, Feminist Legal Methods, 103 Harv. L. rev. 829, 849-56 (1990).

IV Evidentiary Offenses and the Ubiquity of Error

In both Connecticut's irrebuttable presumption of non-residence and eighteenth-century England's irrebuttable presumption that shipwrecked property with obliterated markings was stolen, the legal rule is intentionally blind to the cases in which the presumption does not hold. And thus Bentham's idea of an evidentiary offense is more widespread than we think, and indeed more than Bentham thought. Vast segments of regulatory law perhaps most of it - address a problem or evil with a prohibition not directly framed in terms of that problem or evil. We prohibit driving through a red light rather than prohibiting driving unsafely. American securities law prohibit insiders from buying and selling (or selling and buying) within a six-month period as a way of addressing the problem of trading on inside information, even though some "short-swing" sales are not based on inside information at all. "Firms that violate one of the "per se" antitrust rules - price fixing, for example ${ }^{41}$ - are guilty even when their activities do not restrain trade. People below a certain age may not vote, marry, drive, or drink, even though the problem is irresponsible rather than juvenile voting, marrying, driving, or drinking. Recently enacted laws prohibit people from talking on mobile phones while driving, even though again the problem is dangerous driving or distracted driving and not simply holding a conversation on the telephone. And it is an offense almost everywhere in the United States to drive with a blood alcohol level higher than 0.10 or 0.08 , although once again the evil against which the law is directed is driving while intoxicated and not driving with a certain amount of alcohol in one's bloodstream, and although at least some drivers who are over the legal limit are not in fact intoxicated. ${ }^{43}$ As these and countless other examples demonstrate, we not only sometimes, but usually, regulate indirectly, relying on probabilistic inference instead of aiming the regulatory artillery directly at the ultimate target. 38

Charles Stangor, Content and Application Inaccuracy in Social Stereotyping, in YuehTing Lee, Lee J. Jussim, and Clark R. McCauley, eds., Stereotype Accuracy: Toward 
Appreciating Group Differences 286 (1995).

39

William Blake, Annotations to Sir Joshua Reynolds’s Discourses (1814).

40

41

Securities and Exchange Act of 1934, §16(b), 15 U.S.C. §78p(b) (2004).

United States v. Socony-Vacuum Oil Co., 310 U.S. 150 (1940).

So if our goal is to consider carefully the kind of probabilistically indicative regulation that Bentham's examples illustrate, the question is whether there is any difference in concept between the probabilistic regulations that are all around us and Bentham's presumed offenses? And in considering this question, we might start by supposing that the real difference lies in the difference between the criminal law and other and typically milder forms of regulation. So perhaps it is acceptable to have various privileges and entitlements turn on probabilistic generalizations, but unacceptable for such probabilistic generalizations to provide the basis for imprisoning or fining people who might be wholly innocent. Surely this was what bothered the New York Court of Appeals when in Bunis it refused to allow the criminal conviction of everyone who sold a magazine without a cover. And although the Supreme Court might have misfired when it invalidated the University of Connecticut's residency rules, would we be so quick to criticize the Supreme Court had it invalidated an irrebuttable presumption in Connecticut's criminal law? ${ }^{45}$ What if those claiming in-state tuition who had an out-ofstate residence at any time during the year prior to matriculation were not just subject to higher tuition rates, but were also liable to prosecution for criminal fraud? For the individual who is the exception to the generalization about the class in which she is placed, does this not constitute criminal liability for innocent conduct? And does such liability not escalate the "Where there's smoke, there's fire” adage to a morally unacceptable level?

${ }^{42}$ See Jesse A. Cripps, Jr., Dialing While Driving: The Battle Over Cell Phone Use on the Nation's Highways, 37 Gonzaga L. Rev. 89 (2001); Note, Driving While Distracted: How Should Legislators Regulate Cell Phone Use Behind the Wheel?, 28 J. Legis. 185 (2002).

${ }^{43}$ 44

See State v. Rolle, 560 So. 2d 1154 (Fla. 1990).

See Douglas N. Husak, Reasonable Risk Creation and Overinclusive Legislation, 1 Buff. Crim. L. Rev. 599 (1998).

Yet although the idea of imprisoning people because of the aggregate behavior of some class of which they are a member appears initially draconian, it is hardly clear that this is a fully apt description of the operation of an evidentiary offense. Perhaps most important is the question of notice, for typically a person committing an evidentiary offense knows that the act is unlawful, even if he does not know (or does not believe) that his own act is intrinsically wrong. Even if Mr. Bunis was engaged in an entirely innocent transaction (what that would be is somewhat hard to grasp, but let us give him the benefit of the doubt), he nevertheless was engaged in what he knew or should have known was illegal behavior. Mr. Bunis may not have been doing anything wrong in the largest sense, but we can say that same about the people who run red lights when there are no approaching cars, about the individuals who possess narcotics thay they (and others) believe harmless, and about the corporate officers engage in uninformed (by insider knowledge) open- 
market short-swing transactions in the shares of their own companies. ${ }^{47}$ In countless instances, we do not believe that the prosecution of intentional violators of laws whose background justifications do not apply to them, and whose own individual behavior is (failing to obey the law aside) morally blameless violates any procedural justice. And this is because we understand that fair notice of illegality is typically sufficient to justify the universal application of laws drafted with sufficient breadth that they encompass individuals who know they are breaking the law but are doing nothing else that is fundamentally wicked.

45

Indeed, the Supreme Court continues occasionally to invalidate criminal laws resting too overtly on irrebuttable presumptions, or even presumptions that have the slightly lesser effect of shifting the burden of proof from prosecution to defense for an essential element of an offense. Mullaney v. Wilbur, 421 U.S. 684 (1975), expressed the basic idea, but it is noteworthy that Mullaney is roughly contemporaneous with the irrebuttable cases and thus may embody the same particularist instincts. And although the retreat from Mullaney in Patterson v. New York, 432 U.S. 197 (1977), was less dramatic than was the retreat in the irrebuttable presumption cases, the parallel appears significant. For more recent ebbs and flows of the same idea, see Apprendi v. New Jersey, 530 U.S. 466 (2000); Francis v. Franklin, 471 U.S. 307 (1985); Sandstrom v. Montana, 442 U.S. 510 (1979). For analysis, see Claire Finkelstein, Positivism and the Notion of an Offense, 88 Calif. L. Rev. 335 (2000); John C. Jeffries, Jr. and Paul B. Stephan, Defenses, Presumptions, and Burden of Proof in Criminal Law, 88 Yale L.J. 1325 (1979); Nancy J. King and Susan R. Klein, Essential Elements, 54 Vand. L. Rev. 1467 (2001). 46

Superficial appearances to the contrary, the traditional distinction in the criminal law between crimes malum in se and crimes malum prohibitum, see, e.g., Kinney v. State, 927 P.2d 1289 (Alas. App. 1996); State v. Horton, 51 S.E. 945 (N.C. 1905), is of little assistance in this context. First of all, the distinction now make virtually no difference to any legal consequence except the treatment of unintended killings. See Wayne LaFave, Criminal Law 35 (3d ed. 2000). In addition, even crimes that were traditionally only malum prohibitum still required proof that the individual defendant had actually committed the actually prohibited "malum." Consequently, it was still problematic, as in Bunis and Delmonico, for example, when someone was charged with an offense that was considered not even a malum prohibitum, but only evidence of a prohibitum. It is true that one way of understanding an evidentiary offense is as creating the same relationship between the evidentiary offense and a malum prohibitum as a malum prohibitum bears to a malum in se, but this way of analyzing (and thus justifying) evidentiary offenses appears to have been recognized neither in the case law nor in the literature.

Indeed, the reporting requirement for carrying more than $\$ 10,000$ in cash or its equivalent into or out of the United States provides an ideal example. Because widespread and aggressive notification to travelers of the $\$ 10,000$ rule makes it virtually inconceivable that anyone violating the law was unaware of what was legally required of them, the notice appears to cure much of the objection to punishing people who have themselves done nothing fundamentally wrong. If some international traveler, knowing that he is neither a drug dealer nor a money launderer, intentionally fails to report, believing - correctly - that he lies outside the class of people at whom the law is aimed and believing - also correctly - that he is doing nothing wrong other than failing to 
report, he will attract little sympathy. Under conditions of adequate notice, the individual over-included by an evidentiary offense has little cause for complaint. When one intentionally fails to report the currency that he is otherwise innocently carrying, he has little cause to object to his punishment, just as Mr. Bunis would seem to have had little proper cause to object to being prosecuted for selling coverless magazines, at least on the seemingly well-founded assumption that he knew or should have known ${ }^{49}$ that such sales violated the law. Similarly, were Connecticut to have prohibited anyone with an out-of-state address at any time during the year prior to matriculation from claiming residency, we might be far less sympathetic to even criminal prosecution of those who would knowingly and thus misleadingly make the very claim that the law explicitly forbids.

47

The last example in the text is a description of just the behavior that violates Section 16(b) of the Securities Exchange Act of 1934, an offense aimed at lessening insider trading but which for sales by corporate officers, directors, and significant (ten percent or more of any class of stock) within a six-month period but which requires no insider knowledge whatsoever. 15 U.S.C. §78p(b) (2004).

Even more telling than the way in which ample notice appears to cure much of the objection on behalf of the over-included criminal defendant is the fact that there is no reason to believe that the risks of punishing the innocent are any greater in the case of an evidentiary offense than for a seemingly more "typical" crime. When the law prohibits theft, for example, it prohibits conduct that is intrinsically and not merely indicatively wrong. Nevertheless, in such cases the law still permits a conviction for theft based on proof beyond a reasonable doubt, a standard of proof at the very least somewhat more lenient - and thus somewhat more likely to produce the conviction of the innocent - than absolute certainty. ${ }^{50}$ Moreover, the law routinely allows individuals to be convicted of theft (and anything else) on the testimony of eyewitnesses, even though the inaccuracies of eyewitness testimony are well known, and equally routinely allows criminal convictions based on circumstantial evidence resting on inferential links no stronger than the inferential links underlying an evidentiary offense. ${ }^{52}$ Thus, let us suppose, to reprise our running examples, that ninety-nine percent of the shipwrecked property with obliterated markings is stolen property, that ninety-nine percent of the people entering or exiting the United States with more than $\$ 10,000$ in unreported cash are narcotics dealers or money launderers, and that ninety-nine percent of all sales of magazines without covers are part of fraudulent schemes to deprive publishers or distributors of their rightful revenues. Although in each of these scenarios there is consequently a one percent chance that someone who is not engaged in genuinely wrongful conduct is being punished, and although this is obviously the worry that motivated the New York Court of Appeals in Bunis, the Supreme Court in Bajakajian, and even Bentham, it is hard to see why this constitutes a special problem. There is presumably something like a one percent chance that we are convicting the innocent when we apply a standard of proof beyond a reasonable doubt rather than a standard of absolute certainty, and so too when a conviction rests on circumstantial or scientific or eyewitness evidence whose likelihood of error is at least one percent. ${ }^{53}$ Indeed, the fact that there is, by hypothesis, full notice 
in the evidentiary offense case arguably makes the risk of injustice greater in the nonevidentiary offense case. The likelihood that Mr. Bunis, knowing that sales of coverless magazines were unlawful, was in fact innocent strikes us as being substantially smaller than the chance that Mr. Bunis was innocent under circumstances in which he was convicted under a beyond a reasonable doubt standard of being engaged in the fraudulent

sale of coverless magazines.

The New York Court of Appeals in 1983 did rely on Bunis to strike down a law prohibiting the public possession of an opened alcoholic beverage container, People v. Lee, 58 N.Y.2d 491, 448 N.E.2d 1328, 462 N.Y.S.2d 417 (1983). But although Bunis has not been overruled, the Court of Appeals has subsequently redescribed it as being largely about the lack of proper notice. People v. Bright, 71 N.Y.2d 376, 520 N.E.2d 1355, 526 N.Y.S.2d 66 (1988).

49

On the circumstances under which a person is properly charged with knowing the legal requirements even if he did not actually know them, an instructive example is United States v. Freed, 401 U.S. 601 (1971), in which the Supreme Court concluded, not surprisingly, that a defendant might have been on notice that the law did not treat the civilian possession of hand grenades as "an innocent act." 401 U.S. at 609. On the general issue of knowledge of illegality, see, for example, Sharon L. Davies, The Jurisprudence of Wilfullness: An Evolving Theory of excusable Ignorance, 48 Duke L.J. 341 (1998).

50

See Frederick Schauer and Richard Zeckhauser, On the Degree of Confidence for Adverse Decisions, 24 J. Legal Stud. 27 (1996).

51

See, e.g., Elizabeth F. Loftus, Eyewitness Identification (1996); Elizabeth F. Loftus and James M. Doyle, Eyewitness Testiminy: Civil and Criminal (1997); Daniel Schachter, Searching for Memory (1996); Eyewitness Testimony: Psychological Perspectives (Gary L. Wells and Elizabeth F. Loftus, eds., 1984); Gary L. Wells and Amy L. Bradford, "Good, You Identified the Suspect": Feedback to Eyewitnesses Distorts Their Reports of the Witnessing Experience, 83 J. Applied Psych. 360 (1998).

${ }^{52}$ See United States v. Young, 568 F.2d 588, 589 (8 ${ }^{\text {th }}$ Cir. 1978)(holding that a conviction can rest solely on circumstantial evidence).

The point is illuminated when we compare two different approaches to trafficking in narcotics. In Florida, anyone possessing more than 28 grams of cocaine is guilty of drug "trafficking," even absent proof of any actual selling, distributing, or otherwise transferring cocaine. ${ }^{54}$ Even if the defendant is just a heavy user or is simply stocking up for a rainy day (quite a few rainy days, actually), the definition of the crime, and the penalty that attaches to it, presumes from the quantity that the defendant is trafficking. By contrast, in Illinois it is a distinct crime to possess cocaine with an intent to sell, but the law, unlike the law in Florida, requires proof in each case of an intent to sell. ${ }^{55}$ Yet in practice evidence of possession of a large quantity of cocaine - more than 28 grams, say - is sufficient to allow the jury to infer an intent to sell. ${ }^{56}$ So although the Florida approach takes the form of an evidentiary offense while that of Illinois does not, Illinois, which allows a jury to rely on the very same presumption that motivated the Florida legislature, is no less likely to trap the innocent. Indeed, because Florida situates the 
presumption in a publicly accessible statute, while Illinois allows the same presumption to exist less transparently in the assessments of individual jurors, the Florida approach may well be superior.

There is an issue of here of compound probabilities, and thus there is a case to be made that the standard of proof ought to be higher for an evidentiary offense than for an offense that is directly and not indicatively wrongful. Thus, let us assume that proof beyond a reasonable doubt is equivalent to at least ninety-nine percent certainty. Under this assumption, then if someone is convicted of a non-evidentiary offense -- burglary, for example, for it is far less conceivable that one could actually commit a non-wrongful burglary than that one could be an innocent seller of coverless magazines -- there is no greater than a one percent chance that he has done nothing wrong. But if only ninetynine percent of the sellers of coverless magazines are engaged in genuinely wrongful behavior, and if one can be convicted of the crime of selling a coverless magazine on proof to a ninety-nine percent certainty (and thus when there is a one percent chance that the sale did not occur at all), then there can be almost a two percent chance (100 - $(.99 \mathrm{x}$ .99)) that someone not doing anything genuinely wrong would be convicted. Perhaps the issue of notice alleviates much of the problem, but if and when this is not so, then one solution would be to require a higher burden of proof in evidentiary offense cases than in cases involving prosecution for intrinsically or directly wrongful conduct.

54

Fla. Stat. Ch. 893.135 (1) (2004).

V From Evidentiary Offenses to Indicative Regulation

The conclusion that emerges from the foregoing is that there is less of a difference arguably none at all - between commonly resisted evidentiary offenses and the far more commonly accepted probabilistic features of most of the criminal law, most of the law of evidence, and most or all of the phenomenon of using general rules as a way of controlling and guiding human behavior. Although this conclusion is important in helping to put to rest a persistently lingering particularism - not only Bajakajian but also the current law in Florida, Illinois, and numerous other jurisdictions makes clear that the instincts driving the irrebuttable presumption doctrine are unfortunately alive and well its major significance is in suggesting the ways in which accepting the inevitability of evidentiary offenses opens up a wide range of potentially effective regulatory approaches.

Too many people it seems self-evident that regulation is best aimed at the behavior we wish to control. Yet the lesson of our analysis of evidentiary offenses is that less direct regulatory strategies may often have much to commend them, in part because we have now exposed the very emptiness of the distinction between the direct and the indirect. When Bentham used the alternative label of presumed offenses, he wished to suggest that such offenses are based on a presumption, and on the process of drawing inferences from what we can now directly to what we know only indirectly. ${ }^{57}$ Yet the lesson of our analysis is that the distinction between direct and indirect knowledge is, at best, misleading. When we look out our office windows and observe people walking with open umbrellas (or cars with moving windshield wipers) we presume that it is raining. And we think of this as a presumption, and (or so Bentham and countless others have supposed) a form of indirect rather than direct knowledge, because we have seen no raindrops. We have seen only open umbrellas, but we know from accumulated past 
experience that open umbrellas almost always indicate rain, so we indirectly presume the existence of rain from our direct observation of open umbrellas.

55 56

See People v. Salazar, 672 N.E.2d 803 (Ill. App. 1 Dist. 1996).

See People v. Atencia, 446 N.E.2d 1243 (Ill. App. $1{ }^{\text {st }}$ Dist. 1983); People v. Munoz, 432

N.E.2d 370 (Ill. App. 3 Dist. 1982).

Yet although the inferential process is obvious when we infer the presence of rain from the observation of open umbrellas, there is also an inferential process when we observe the rain itself. When we see what we perceive to be actual raindrops and thus "infer" that it is raining, we are still drawing inferences, most significantly the inference from what appears to us to be rain to the conclusion that it is rain. And although describing this process as an "inference" may look peculiar from our own perspective - when we are "inferring” the accuracy of our own observation - it strikes us as far less strange when we are referring to the observations of others, especially in light of what we know about the hardly perfect accuracy of sensory perception. 59 So when we move from Jack's perception that it is raining to Jill's conclusion, based on Jack's perception, that it is raining, it becomes more clear that there is no escaping the process of inference. For Jill to conclude that it is raining requires her to infer that Jack's observation was accurate, that Jack's report of Jack's observation was accurate, and that Jill's understanding of Jack's report was accurate as well. All of these are inferences - probabilistic based on past experience and not by any means certain - and thus not different in kind from the type of inference that undergirds the typical indirect presumption. Like the distinction between direct and circumstantial evidence, therefore, the distinction between direct observation and indirect inference typically overstates the reliability of sensory and thus allegedly direct evidence, and equally typically understates the inferential nature of the sensory process.

57

See Edna Ullman-Margalit, On Presumption, 80 J. Phil. 143 (1983); Edna UllmanMargalit and Avishai Margalit, Analyticity by Way of Presumption, 12 Can. J. Phil. 435 (1982).

The umbrella example is part of the rhetorical arsenal of American trial lawyers, who commonly use it to demonstrate to jurors the frequent reliability of so-called

“circumstantial” evidence. Cf. United States v. Andrino, 501 F.2d 1373, 1378 (9 Cir. 1974) ("Circumstantial evidence is not less probative than direct evidence, and, in some instances, is even more reliable.”).

The inferential process of determining that it is raining from our observation of open umbrellas is thus not significantly different from the inferential process involved in presuming that it is raining from Jack's account, to us, that he saw raindrops. Recognizing the presumptions involved in both of these inferential processes thus significantly weakens the distinction between direct and indirect accounts, and, more importantly, weakens as well the supposed distinction between evidentiary and nonevidentiary offenses. Recognizing that inferences are involved in virtually all observations highlights the evidentiary nature of even non-evidentiary offenses, and so makes clear that just as there is no a priori reason to prefer direct to circumstantial 
60

evidence, nor, pace Bentham and his legions of followers, is there any a priori reason to prefer non-evidentiary offenses to evidentiary ones.

Yet a worry appears to linger. Even after we have undercut the alleged distinctions between direct and indirect, presumed and non-presumed, and evidentiary and nonevidentiary, a residual concern remains. Surely there is a difference between, for example, making murder a crime and making possession of a smoking gun a crime (and not simply as evidence of some other crime). And surely we understand the difference between the crime of burglary and the crime of possession of burglar tools, even as we continue to acknowledge the propriety of criminalizing both.

59 60

See note 51 supra.

See note 58 supra.

Yet although there appears to be a difference between these types of offenses, that difference turns out to dissolve whenever we formulate a crime in terms other than intrinsic wrongness. ${ }^{62}$ Whenever an offense or regulatory target is formulated instrumentally, to advance rather than simply to restate some background justification, the distinction between the definition of an offense and the definition of the evidence allowable to establish it is weakened substantially. Thus, the difference between the offense of driving greater than sixty-five miles per hour and the offense of causing a radar speed detector to indicate a speed in excess of sixty-five miles per hour may appear, as with the distinction between the crime of murder and the hypothetical crime of possessing a smoking gun, to be a distinction between the evidence and the offense. And so too with the distinction between the offense of driving while intoxicated and the offense of causing a breathalyser to indicate a .10 or .08 blood alcohol level. But the offense of driving at a speed of greater than sixty-five miles per hour is itself an imperfect indicator of the deeper concern for unsafe driving, and so too with driving while intoxicated, for not all instances of driving in excess of some posted speed are unsafe, nor are all instances of driving while intoxicated. Rather, these behaviors are so highly indicative of the deeper concern that we prohibit the behaviors even as we recognize that they are probabilistic and not certain markers of the true concern. But once we understand this, it is no longer clear that the category of presumed offenses is either small or problematic. A presumed or evidentiary offense is one in which the offense is not intrinsically wrong but is made wrong because it indicates the presence of something more deeply or intrinsically wrong. But we now see that this definition of an evidentiary offense, a definition that looked initially troubling, applies to almost all of the traffic offenses that probabilistically but not certainly indicate unsafe driving, to most of the possession offenses (for child pornography, burglar tools, and sawed-off shotguns, for example), to various non-reporting offenses (like that in Bajakajian, but also like almost any corporate reporting requirement), and to countless other offenses that are described in ways that are indicate rather than descriptive or definitional of our ultimate concern. And thus the distinction between the real crime of murder and the hypothetical crime of possessing a smoking gun turns out to be a distinction based solely on our (largely correct) instincts about the probabilistic reliability of the indicator and the consequences in those cases in which the probabilities produce the wrong result. Were possession of a 
smoking gun to indicate murder $99.9999 \%$ of the time, and were the penalty for murder to be six months in the penitentiary rather than life imprisonment or capital punishment, it is hardly clear that making the possession of a smoking gun a crime would seem so problematic.

61 62 See note 14 supra.

We refer to "intrinsic wrongness" here not to take a position on the soundness (or not) of utilitarianism or any other meta-ethical framework. Rather, the phrase is designed to make clear that the analysis here, which may be self-evident to utilitarians, is equally applicable to regulation under non-utilitarian perspectives.

Before pursuing this line of argument to its logical conclusion, it is worth distinguishing two types of evidentiary offense. For one type there is an actual causal relationship between the underlying offense and the evidence that we may at times choose to define as the offense. Many murders do indeed cause smoking guns, and our inference from the smoking gun to a murder, even if imperfect, is still based on the fact that many murders do cause there to be smoking guns, just as many rainfalls do cause there to be open umbrellas on the street. And when such a causal relationship exists, our instincts are often more comfortable with evidentiary offenses or evidentiary liability.

But let us contrast the (probabilistically) causal offense with the true indicative offense. With such an offense, an observable behavior still indicates the likelihood of a deeper offense, but here there is no causal connection between the deeper offense and the observable behavior. Consider the relationship between broken factory windows, malfunctioning gauges, and wildly inaccurate clocks, on the one hand, and unsafe working conditions, such as inadequate sound control, insufficient supply of protective clothing, and poorly designed guards on dangerous machinery, on the other. Because broken factory windows, say, and insufficient attention to worker safety often have a common cause - employer negligence or inattention - there is a correlation between the two phenomena, even though the unsafe working conditions do not cause the broken windows, nor do the broken windows cause the unsafe worker conditions. But even though there is no causation connecting the two phenomena, the existence of a correlation makes the presence of broker windows and indicator, and often a highly reliable one, of an increased likelihood of unsafe working conditions.

Because broken windows indicate the presence of something that is our deeper concern, could we not then treat the presence of broken windows in just the same way that we treat the failure to report the possession of $\$ 10,000$ or more in currency or its equivalent by those entering or leaving the United States? That is, could we make having broken windows and offense in itself, or the predicate for some other form of regulatory intervention, not because we care about broken windows, but instead because controlling those who allow there to be broken windows in their factories might turn out to be an efficient method of controlling the very people who maintain unsafe conditions for their workers. Were this approach to be followed., the wrong of having a factory with broken windows would then constitute an indicative wrong, usefully contrasted with the seemingly more direct wrong of having a factory with unsafe working conditions, and 
also usefully contrasted with a causal evidentiary wrong, such as deeming it unlawful to have more than a designated number of reported injuries per month. 63

See Judith Jarvis Thomson, Liability and Individualized Evidence, in Rights, Restitution and Risk: Essays in Moral Theory 225 (1986).

64

Here we borrow in a different context and for different purposes the famous example in James Q. Wilson and George L. Kelling, Broken Windows: The Police and Neighborhood Safety, The Atlantic Monthly, March, 1982, at 32.

The question then is whether the absence of a causal relationship between the wrong and the indicator - as in the broken windows example - makes the purely indicative offense different in important ways from the presumed or evidentiary offense that is grounded on an actual causal connection between the indicator and the wrong. Although most instances of unreported cash carrying, obliterated markings on shipwrecked property, and sales of coverless periodicals are caused by the very illegal activity with which we are primarily concerned, is the issue transformed when no such causal relationship exists. Perhaps there is nothing unjust about prosecuting Mr. Bunis for selling his coverless periodicals, for it is highly likely that his prosecution was engaging in an activity almost certainly caused by other illegal activities that he committed. But is there not something different and more unjust in prosecuting or otherwise regulating someone for doing something that appears to have no connection with a real concern except the presence of a common cause?

There is, to be sure, a difference between the causally-grounded evidentiary offense and the purely indicative offense, but it is not so clear that either justice or good regulatory policy should turn on that difference. Consider the case in which the causal relationship is absent, and thus in which the argument against evidentiary offenses ought to be the strongest. So in the workplace safety example, we know that certain features of a workplace likely indicate unsafe working conditions even as we know that unsafe working conditions are in no way the cause of those workplace features. Broken windows are one such feature, and another is the presence of non-functioning monitoring gauges, even gauges designed to measure conditions that are not themselves safetyrelated. $^{66}$ Similarly, a very high level of production might be a condition probabilistically indicating but perhaps only rarely causing unsafe working conditions. Under these circumstances, would there be something untoward in punishing people for having broken windows, or malfunctioning gauges, or perhaps sloppy trash disposal, on the assumption that none of these indicators were intrinsically harmful or causally related to something intrinsically harmful? Initially, we bridle at the prospect. Should those who are completely innocent be punished or regulated simply because their innocent behavior happens, imperfectly, to indicate the presence of wrongful or dangerous behavior for most but certainly not all people or, in this case, business enterprises? 65

The assumption here is that it would be possible for a workplace to have a large number of accidents for reasons other than the lack of safety of the workplace itself. It might be an unusual month, for example, or for some reason some workplace might have more than its share of clumsy workers. Nevertheless, in most cases a high accident rate will not only be indicative of unsafe workplace conditions, but will also have been causes by those unsafe workplace conditions. 
If the issue is one of civil regulation, where imprisonment is not an option, and where the standard of proof would be far less than proof beyond a reasonable doubt, the case for probabilistic and indicative regulation, or at least the case against a blanket prohibition of such regulation, appears compelling. And the case is no less strong when we are dealing with criminal and not civil regulation. It may seem unfair to punish a business for having broken windows at its factory, but this is no less unfair than punishing a safe driver who drives in excess of the speed limit on a clear dry traffic-free morning. In both cases the costs of locating the genuinely harmful behavior - unsafe working conditions and unsafe driving, respectively - are seen to be excessive. In the broken window case it might be too costly or too intrusive to search every factory for less visible safety violations, and in the speed limit case it might be too costly or too intrusive or too open to abuse to require (and allow) police officers to determine on a rule-free case-by-case basis who is driving safely and who is not. So in both cases the visible indicators operate as heuristics to produce the correct result in the vast majority of cases. Punishing people on the basis of heuristics seems initially unfair, but now that we see that punishing people for breaking rules rather than breaking the justifications lying behind them is also a form of punishment on the basis of heuristics, it is hard to accept the objection. And having seen as well that in an imperfect world any form of punishment risks punishing some people who are totally innocent, it is also hard to take the actual or potential over-inclusiveness of indicative regulation as being any more objectionable than any other form of rule-based regulation and the inevitably probability-based evidentiary determination of culpability or liability. So long as there is adequate notice of what activity is liable for punishment or regulation, it is a misplaced concern that worries about innocence in the case of indicative offenses but not with respect to rule-based regulation and not with respect to prosecution or regulation based on allegedly "direct" but far from certain evidence.

66

Consider, for example, a paint factory whose meters for measuring the tonal consistency of the paint were both dirty and substantially inaccurate.

This is not to say that we should be unconcerned with the probability of convicting the innocent or over-regulating the conscientious. It is to say that there is no reason to believe that the risks of over-regulation are any more located in so-called evidentiary offenses than they are in rules generally and the admission of uncertain evidence generally. Any regulatory practice will aim to achieve - in light of the potential restriction and in light of the social goals sought to be achieved - an appropriate balance between the Type I errors of over-regulation of the innocent and the conscientious and the Type II errors of under-regulation of the guilty and the irresponsible. This balance will vary across forms of government control and across social goals, but it is misguided to think that we eliminate or even reduce the Type I errors by avoiding evidentiary regulation, at least unless we are equally concerned with the Type I errors that emerge from rule-based guidance, from regulatory incompetence (or worse), and from the epistemological risks of any system of evidence. It is no mistake to try to limit the phenomenon of over-regulation, but it is a mistake to believe that there is something about evidentiary or indicative offenses, or regulation by generalization as a whole, that makes it the prime locus of the problem. 
Nor does it follow from the above that regulating purely indicative activity will always or even usually be a wise policy. Especially when the causal relationship is absent, it may often be too easy for a potential miscreant to manipulate the system by remedying the indicator while leaving the problematic activity untouched. We do not, after all, want people who operate genuinely unsafe factories to deflect the law's attention just by replacing the broken windows. Indeed, in many cases this possibility will undercut the utility of criminalizing indicative behavior where such behavior is not the causal consequence of some genuinely problematic act. Moreover, although in this Essay we have talked primarily about the probabilistic inference from evidentiary offense to intrinsic wrong, this is but shorthand for the more comprehensive expected value analysis that would undergird the proper use of any such indicator, and that would, most importantly, weigh the expected benefits of any regulatory strategy against its expected costs. Indeed, such a full analysis will recognize that at times the proscription of purely indicative behavior will produce valuable rather than perverse incentives. If we treat possession of stolen property as an offense just because it probabilistically indicates theft, most of the people subject to prosecution will have actually committed a theft or knowingly abetted those who have. But even some who are guilty of nothing but stupidity may have reason to alter their behavior in socially desirable ways. If I obtain a flat-screen television off the back of a truck in a New Jersey Turnpike rest area, and if I am then prosecuted for possession of stolen property, the likelihood that I have actually stolen the television will be small, but the likelihood that a regime of such prosecutions will alter the market for stolen goods in socially desirable ways is considerably larger.

VI Conclusion: Expanding the Regulatory Repertoire

Although there are thus risks to thinking too easily that less direct regulation is preferable to more direct regulation, the basic lesson is that evidentiary, presumed, or indicative offenses may be less different from the standard regulatory or criminal law prototype than is commonly believed. Having a criminal or civil penalty rest on an imperfect generalization is less unusual than we have supposed, less abhorrent to justice than numerous courts even to the present day have believed, and more properly part of the regulatory repertoire than many people have appreciated.

Evidentiary offenses do create some risk of punishing the genuinely innocent, ${ }^{67}$ but so too, we now see, does virtually every other aspect of any regulatory or punitive system. In an imperfect world such imprecision is inescapable, and although it would plainly be desirable to reduce the possibility of wrongful punishment within the constraints of satisfying the other goals that any system of regulation or punishment must serve, ${ }^{68}$ there is little reason to believe that serving this goal requires that the conditions of criminal or civil liability not be defined in terms of imperfect generalizations. It could hardly be otherwise, and although we owe to Bentham the original conceptualization of the idea of an evidentiary offense, his mistake may only have been in believing that evidentiary offenses were the exception rather than the rule.

The lesson of evidentiary offenses, however, is not restricted to understanding Bentham or even to the criminal law generally. The broader implications can and should inform regulatory practice generally. Typically, regulatory practice identifies the target of 
concern, assumes that the target will be specified as such in any regulation, and then proceeds to inquire into the optimal method of ensuring compliance. Of course existing regulatory practice does examine the relative advantages of ex ante and ex post regulation, the various institutional forms of enforcement, and the size of any penalties, among other issues. But through all of this the practice of regulatory design continues to assume that if we are concerned about $\mathrm{x}$ then we should regulate $\mathrm{x}$. But now that we have exposed both the ubiquity and the acceptability of evidentiary offenses, we are better positioned to challenge the assumption that concerns about $\mathrm{x}$ must be embodied in some form of regulation of $\mathrm{x}$. If the regulation of $\mathrm{y}$ will lead to less $\mathrm{x}$ and also to lower compliance costs than will the regulation of $\mathrm{x}$ itself, then there is no a priori reason to exclude the regulation of $\mathrm{y}$ from the menu of options available for the control of $\mathrm{x}$. Regulating $\mathrm{y}$ in order to control $\mathrm{x}$ may strike some people as unjust, especially when those who are doing y are wholly innocent of $x$-ing. ${ }^{69}$ But there is nothing unjust about this at all, and certainly nothing specially or uniquely or unusually unjust. Such imprecision and its consequences are simply one facet of regulatory design, and a facet no different from the various other facets that in different but neither more nor less severe ways represent the inevitable concomitants of the probabilistic world that we inhabit. 67

An important analysis on this point is Alan Wertheimer, Punishing the Innocent Unintentionally, 20 Inquiry 45 (1978).

68

Among those goals is the goal of punishing the guilty, and thus "to insure [that] the probability of convicting the innocent really reaches zero may require the willingness to accept a probability of conviction for the guilty which is considerably less than one.” Lester Thurow, Equity Versus Efficiency in Law Enforcement, 18 Pub. Pol. 452 (1970).

69

Careful design of a system of evidentiary regulation would need to take account of two different kinds of innocence. In one, such as the classic case of mistaken identity, the person who is innocent is really and wholly innocent. In another, however, the person who is nominally innocent has in fact done what we think they have done, but we are mistaken in the inference we draw from that fact. There is a difference, therefore, between the case in which Mr. Bunis is charged with selling coverless magazines and it turns out that he only resembles the person who is selling coverless magazines, and the case in which Mr. Bunis is correctly identified as selling coverless magazines, but in which it is incorrectly presumed on the basis of that fact that he is engaged in a fraudulent transaction. A well-developed system of evidentiary regulation will of course be sensitive to the balance between Type I and Type II errors - between the errors of erroneous conviction and the errors of erroneous acquittal (or their non-criminal regulatory or civil equivalents), and in doing so will take account not only of the frequency but also of the harm of different kinds of errors, harms that may be greater when we sanction the totally innocent than when we sanction those whose mistaken sanction is in some respects less of a mistake. 
